\title{
Contract management and performance characteristics: An empirical and managerial implica- tion for Indonesia
}

\author{
Kamaruzzaman Muhammad $^{a^{*}}$, Oussama Saoula ${ }^{b}$, Mustafa Rashid Issa $^{c}$ and Umair Ahmed ${ }^{d}$
}

${ }^{a}$ Faculty of Accountancy, Universiti Teknologi MARA Malaysia, Malayisa

${ }^{b}$ School of Business Management, College of Business, Universiti Utara Malaysia, 06010 Sintok Kedah Malaysia

${ }^{c}$ Department of Law, Ishik University Iraq, Iraq

${ }^{d}$ Arab Open University Bahrain, Bahrain

CH R O N I C L E

Article history:

Received: March 15, 2019

Received in revised format: April

142019

Accepted: April 19, 2019

Available online:

April 19, 2019

Keywords:

Contract management

Firm performance

Project delivery

Indonesia

\section{A B S T R A C T}

\begin{abstract}
This study intends to cover the relationship between contract management and performance characteristics from the context of Indonesia. To address this objective, contract management is observed as the main independent variable while performance through nine items is considered as dependent variable. A questionnaire is developed through some selected factors and distributed among various respondents, dealing directly or indirectly with the projects. A sample of 70 respondents is finalized with no missing values. Empirical findings suggest that for the firm performance different variables such as nature of the solution, cost \& benefit analysis are significantly associated with the contract length. While project delivery and project quality are negatively associated with the contract length. Findings of the study are highly recommended for the contract managers and similar individuals, responsible for the smooth business performance. However, future studies can be conducted with the addition of more explanatory factors for contract management with better sample size. Managerial implication of the study defines that Government and construction companies should reconsider the stated factors for the improved results through resolution of the conflict with the customers, cost benefit analysis and timely delivery of the project with budgetary compliance.
\end{abstract}

\section{Introduction}

To achieve the strategic objectives, all types of business organizations are dealing with the projects through various management skills and expertise (Hobday, 2000; Kerzner \& Kerzner, 2017). For business success, projects are now becoming the mainstream for the success or failure (Morris \& Jamieson, 2004). To get the competitive advantage over rivals, business firms deal with the complex situations under the title of ambiguity and challenges. To create a strategic change, it is very much obvious to mobilize the resources in the present economy. The idea of contract management is directly associated with the performance of the business. Various benefits through contract management for the business organizations are identified in present literature (Turner \& Simister, 2001; Purnama, 2014; Chielotam, 
2015; Mowlaei, 2017; Albasu \& Nyameh, 2017; Maroofi, Ardalan, \& Tabarzadi, 2017; Kucukkocaoglu \& Bozkurt, 2018; Maldonado-Guzman et al., 2018). For instance, proper contract management can significantly lower the factor of risk and uncertainty for the business and customer as well (Haapio \& Siedel, 2017; Mo et al., 2001; Wiengarten et al., 2016). At second, contract management covers the title of financial optimization, helping the business to protect itself from renewal of some unwanted services. At third, factor of productivity is on major concern in the present world. Operational efficiency of the business can only be achieved if proper contract management system is applied for the better outcome. Various indicators have been examined in present literature to cover the title of contract management. Some have explained it through conflict resolution with the customer through contract length, satisfaction with project goals, resolution of dispute and acceptance criteria for product and service as explained by Mutua et al. (2014). A sound contract management system covers the success for the procurement as it ensures the performance of contractor as per the defined schedule, time, specification of the contract and specification, defined in the contract. The idea of contract management also known through contract administration, covers the concept of bidding and reward of the contact. When the contract is signed, various resources required for the contract are provided by the procuring entity, covering the budgetary funds and relevant staff for the effective implication of contract (Ajayi et al., 2015; Bayliss et al., 2004; Kartam \& Kartam, 2001; Oberlender \& Oberlender, 1993). Various governments across the world economy have lost significant amount due to weak contract management practices. Such practices can be reviewed through regulatory compliance defined by the relevant authorities or departments in the region. In addition, business performance has several dimensions. Various studies have explored performance through financial measures. Nonetheless, non-financial indicators have got less attention. Among the various issues, the key indicators cover the resolution with the customer, delivery of the project, quality factor, budgetary compliance and satisfaction of the customer (Klijn \& Koppenjan, 2016; Mutua et al., 2014; Santhi \& Gurunathan, 2014; Anyanwu, et.al 2016; Jones \& Mwakipsile, 2017; Mosbah et al., 2017; Malarvizhi et al., 2018, Le, et al. 2018). From the context of Indonesia, various firms are providing their services in the field of project management. Experienced consultants are dealing with the necessity of the good projects regarding their planning, management of various resources, management of time \& budget, project coordination, suppliers \& sub-contractor management, reporting of the project as per international standards, stakeholder's consideration, marketing and communication of the projects.

The purpose of this study is to investigate the factor of contract management for business performance in the region of Indonesia. The rest of the study is as follows. Present section covers some introductory portion. Section two and three deal with literature and variable. Section 4 provides description about sample and methods. Section five explains the results with discussion. Last section explains the conclusion part.

\section{Literature Review}

Literature context for contract management has provided little work specifically with reference to the performance of the business. However, the influence of contracting on contract management is observed in different studies (e.g. Anigbogu \& Nduka, 2014; Chang \& Liang, 2015; Broekhuis \& Scholten, 2018). The focus of their studies was on the service sector with the consideration of customer business relationship. Data were collected through multi method covering the approaches like documents, interviews and type of contact between buyer and the sellers. It is expressed that contract between the both parties provides a comprehensive way of dealing with the formal relationship and management expertise. Selviaridis and Norrman (2015) examined the idea of management performance-based contracts or PBC in logistics services. After detailed review of present literature, authors argued that limited literature had been available in this regard. Research design covers the title of multi case method and three cases of logistic providers was selected through purposive sampling technique. They found that PBC provides significant path for the achievement of strategic objectives of the business with the risk and reward sharing approach. Meanwhile, authors explained that contract management covers the process and resource investment with the fair incentives. 
There are also several studies contemplated the management practices through outsourced performancebased contacts (Blumenberg et al., 2009; Domberger et al., 2000; Logan, 2000; Omizzolo Lazzarotto et al., 2014). Authors argue that such practices are complex in nature and there is a significant need of creating long term relationship with the business contracts and performance. Rasheli (2016) examined the costs involved in the procurement contracts in public sector from the perspective of client. Using the institutional economics and transitional cost approach multiple case study design was used and reported the fact that high information and negotiation costs were playing major role in the performance of the government. Meanwhile, it is also expressed that lower level of governments at local level may face high transaction cost in all stages of procurement. Mchopa (2015) explained that contract management is an important task in public procurement while taking the value of money. The study found that contract management covers the title of quality management of the cost, its controlling, and effective findings for the money achievement.

Pappas et al. (2019) observed the financial perspective of loan contract with the presence of real earning management (REM). Like other measures, REM is assumed to very much difficult to measure for the outsiders. Their study have focused on the REM and its link with the interest rate spread and more demand for the higher collateral. It is expressed that great REM could lead to higher yield of bond and collateral requirements. Some other studies have also provided their significant contribution in prevailing literature for contract management and business practices (Kamminga, 2015). While others have taken its idea in the field of supply chain practices (Brun \& Moretto, 2012). Besides, some studies are conducted for exploring the concept of contract and risk management as well (Adams, 2008; Chow et al., 2015; Gao, 2015; Haapio \& Siedel, 2017; Liu et al., 2015; Mo et al., 2001; Ryall \& Sampson, 2016; Simon, 1999; Zhi, 1995). While some studies have taken the idea of contract management system through internet and computer-based programs for the building construction bids (Crookshanks, 2006). Besides, improving the health system for the government through contract management is also observed and empirically justified (Alexander \& Morrisey, 1989; Goddard, 2000; Hyvönen \& Järvinen, 2006; Loevinsohn \& Harding, 2005; Sackler \& Levin, 1993; Soeters \& Griffiths, 2003).

After detailed review of both theoretical and empirical studies, significant gap is observed from the context of Indonesia. A limited quantity of work is presented in earlier studies, ignoring the interaction between the contract management and business performance. Due to this gap in the literature, this study has provided a managerial implication of contract management for improved business outcomes.

\section{Description of the Variables}

\subsection{Contract Management}

Numerous researchers have explained the contact management through those projects which are interlinked in business organizations. The factor of length of the contract indicates the time period required to complete a specific contact (Mo et al., 2001). Some studies indicate that contract length is a key factor to affect the business repute as it provides the customer with better view about the commitment and effectiveness. In present study, the factor of contract management also covers the titles of dispute resolution with the customer, satisfaction with the project goals, and acceptance criteria for the products and services. These items integrates the business capability for their relationship with the customers, tackling the issues with the customers, and the way business is satisfied with the achievement of its goals. All these stated items are added in the questionnaire through five-point Likert scale.

\subsection{Business Performance}

Business performance is a complex phenomenon and its financial measures has received significant attention and much literature work has been presented (e.g. Flammer, 2015; McGuire et al., 1988; Orlitzky et al., 2003; Post \& Byron, 2015; Qiu et al., 2016; Waddock \& Graves, 1997). The linkage of business performance to contract management is very little addressed and confined work is conducted in this 
regard. For instance, Mutua et al. (2014) examined the association between contract management with the performance of outsourced projects. Though, the concept of business performance can also be examined through conflict management with the customers (Chow et al., 2015; Duarte \& Davies, 2003; Kochan et al., 2003; Thomas, 1992). Factors like cost \& benefit analysis can also be utilized to reflect the business performance (Husted \& de Jesus Salazar, 2006; Jenkins, 1999; Pearce et al., 2006; Quah \& Haldane, 2007). The present study has taken the dimensions like nature of solution, effectiveness of solution, effectiveness in future, support for the solution, cost benefit analysis, project quality, project delivery, budgetary compliance and finally customer satisfaction as the core dimensions for business performance as identified in the studies of (Klijn \& Koppenjan, 2016; Mutua et al., 2014).

\section{Methods and Sample of the study}

This study uses applied quantitative approach. In the very first step, a structural questionnaire is developed for the contract management and business performance. Overall 13 items have been added in the questionnaire, covering four for the contract management and nine for the business performance. Demographic details explain the gender, age, job tile and job position of the respondents. A sample of 100 questionnaires were distributed in the first attempt to the targeted respondents who are associated with the different public \& private contracts. After two weeks of distribution overall 83 questionnaires were collected. Detailed observation reflects some of the responses are missing from 13 questionnaire. A final sample of 70 respondents with no missing observation is finally selected. Descriptive analysis are performed to describe the demographic details of the respondents. For empirical association, regression analysis technique is applied.

\section{Results and Discussion}

Table 1 presents demographic details about respondents. For the sample of 70 respondents, 58 are males and 12 are females covering sample portion of 82.9 and 17.1 percent, respectively. The distribution of age frequency covers 57.1 percent for those in range of 21-30 years, 31.4 percent in 31.40 years, 8.6 percent in range of 41-50 years. As per the distribution of job tile, 6 are the project manager, 4 are the architect while 44.3 percent respondents engineer. 17 respondents are the quality surveyor while 12 belongs to some other jobs. For job position, 9 are non-executive and 40 are executive. Besides, 14 are managerial and 7 are others.

Table 1

Demographic Details

\begin{tabular}{|c|c|c|c|c|c|}
\hline & & Frequency & Percent & Valid Percent & Cumulative Percent \\
\hline \multirow{3}{*}{ Gender } & Male & 58 & 82.9 & 82.9 & 82.9 \\
\hline & Female & 12 & 17.1 & 17.1 & 100.0 \\
\hline & Total & 70 & 100.0 & 100.0 & \\
\hline \multirow{5}{*}{ Age } & $21-30$ years old & 40 & 57.1 & 57.1 & 57.1 \\
\hline & $31-40$ years old & 22 & 31.4 & 31.4 & 88.6 \\
\hline & $41-50$ years old & 6 & 8.6 & 8.6 & 97.1 \\
\hline & 50 and above & 2 & 2.9 & 2.9 & 100.0 \\
\hline & Total & 70 & 100.0 & 100.0 & \\
\hline \multirow{6}{*}{ Job title } & Project Manager & 6 & 8.6 & 8.6 & 8.6 \\
\hline & Architect & 4 & 5.7 & 5.7 & 14.3 \\
\hline & Engineer & 31 & 44.3 & 44.3 & 58.6 \\
\hline & Quantity Surveyor & 17 & 24.3 & 24.3 & 82.9 \\
\hline & Others & 12 & 17.1 & 17.1 & 100.0 \\
\hline & Total & 70 & 100.0 & 100.0 & \\
\hline \multirow{5}{*}{ Job position } & Non-executive & 9 & 12.9 & 12.9 & 12.9 \\
\hline & Executive & 40 & 57.1 & 57.1 & 70.0 \\
\hline & Managerial & 14 & 20.0 & 20.0 & 90.0 \\
\hline & Others & 7 & 10.0 & 10.0 & 100.0 \\
\hline & Total & 70 & 100.0 & 100.0 & \\
\hline
\end{tabular}


Pairwise correlation coefficients are presented in Table 2 for all the variables of the study. Highly positive and significant correlation is experienced between effectiveness of solution (EOS) and effectiveness in future (EIF). While other variables like EOS and NOS, NOS \& EIF, between EOS and contract length $(\mathrm{CLNGTH})$ are presenting significantly positive but moderate level of correlation with each other. The factor of support for the solution (SFS) has a significant and moderate level of relationship with CLNGTH; .453. Meanwhile CLNGTH is significantly and positively associated with acceptance criteria for product/service. Meanwhile, the factor of budgetary compliance (BC) has a significant and positive correlation with integral nature of solution, effectiveness of solution, effectiveness in future, cost \& benefits, contract length, satisfaction with the project goals, and acceptance criteria for product/service. Overall problem of high correlation is diagnosed through mean score of VIF and individual VIF. Mean variance inflation factor is 1.82 , indicating no problem for the high correlation between variables, hence considered for the regression analysis.

\section{Table 2}

Pairwise Correlation Coefficients

\begin{tabular}{|c|c|c|c|c|c|c|c|c|c|c|c|c|c|}
\hline Variables & (1NOS) & (2EOS) & (3EIF) & (4SFS) & (5CB) & (6CLNGTH) & (7SWPG) & (8ROD) & (9ACFPS) & (10PQ) & (11OND) & (12BC) & $(13 \mathrm{CS})$ \\
\hline (1) NOS & 1.000 & & & & & & & & & & & & \\
\hline (2) EOS & $\begin{array}{c}0.561^{* * *} \\
0.000\end{array}$ & 1.000 & & & & & & & & & & & \\
\hline (3) EIF & $\begin{array}{c}0.489^{* * *} \\
0.000\end{array}$ & $\begin{array}{c}0.731^{* * *} \\
0.000\end{array}$ & 1.000 & & & & & & & & & & \\
\hline (4) SFS & $\begin{array}{c}0.265^{* *} \\
0.027\end{array}$ & $\begin{array}{c}0.392^{* *} \\
0.001\end{array}$ & $\begin{array}{l}0.177 \\
0.142\end{array}$ & 1.000 & & & & & & & & & \\
\hline (5) $\mathrm{CB}$ & $\begin{array}{c}0.355^{* * *} \\
0.003\end{array}$ & $\begin{array}{c}0.598^{* * *} \\
0.000\end{array}$ & $\begin{array}{c}0.624^{* * *} \\
0.000\end{array}$ & $\begin{array}{l}0.191 \\
0.113\end{array}$ & 1.000 & & & & & & & & \\
\hline (6) CLNGTH & $\begin{array}{c}0.393^{* *} \\
0.001\end{array}$ & $\begin{array}{c}0.405^{* *} \\
0.001\end{array}$ & $\begin{array}{c}0.453^{* * *} \\
0.000\end{array}$ & $\begin{array}{c}0.426^{* * *} \\
0.000\end{array}$ & $\begin{array}{c}0.621^{* * *} \\
0.000\end{array}$ & 1.000 & & & & & & & \\
\hline (7) SWPG & $\begin{array}{c}0.338^{* *} \\
0.004\end{array}$ & $\begin{array}{c}0.608^{* * *} \\
0.000\end{array}$ & $\begin{array}{c}0.648^{* * *} \\
0.000\end{array}$ & $\begin{array}{l}0.179 \\
0.138\end{array}$ & $\begin{array}{c}0.561 * * * \\
0.000\end{array}$ & $\begin{array}{l}0.608 \\
0.000\end{array}$ & 1.000 & & & & & & \\
\hline (8) ROD & $\begin{array}{c}-0.144 \\
0.233\end{array}$ & $\begin{array}{c}-0.076 \\
0.532\end{array}$ & $\begin{array}{l}0.001 \\
0.996\end{array}$ & $\begin{array}{l}0.271 \\
0.023\end{array}$ & $\begin{array}{l}0.232 \\
0.053\end{array}$ & $\begin{array}{c}0.272^{* *} \\
0.023\end{array}$ & $\begin{array}{l}0.055 \\
0.652\end{array}$ & 1.000 & & & & & \\
\hline (9) ACFPS & $\begin{array}{l}0.168 \\
0.164\end{array}$ & $\begin{array}{c}0.365^{* * *} \\
0.002\end{array}$ & $\begin{array}{l}0.349 \\
0.003\end{array}$ & $\begin{array}{l}0.291 \\
0.014\end{array}$ & $\begin{array}{c}0.546^{* * *} \\
0.000\end{array}$ & $\begin{array}{c}0.634^{* * *} \\
0.000\end{array}$ & $\begin{array}{c}0.455^{* *} \\
0.000\end{array}$ & $\begin{array}{c}0.483^{* *} \\
0.000\end{array}$ & 1.000 & & & & \\
\hline (10) PQ & $\begin{array}{c}-0.075 \\
0.539\end{array}$ & $\begin{array}{l}0.075 \\
0.535\end{array}$ & $\begin{array}{l}0.040 \\
0.745\end{array}$ & $\begin{array}{c}-0.053 \\
0.662\end{array}$ & $\begin{array}{l}0.049 \\
0.684\end{array}$ & $\begin{array}{c}-0.067 \\
0.582\end{array}$ & $\begin{array}{l}0.084 \\
0.488\end{array}$ & $\begin{array}{l}0.255 \\
0.033\end{array}$ & $\begin{array}{l}0.173 \\
0.152\end{array}$ & 1.000 & & & \\
\hline (11) OND & $\begin{array}{l}0.050 \\
0.682\end{array}$ & $\begin{array}{c}0.285^{* *} \\
0.017\end{array}$ & $\begin{array}{l}0.039 \\
0.746\end{array}$ & $\begin{array}{l}0.096 \\
0.431\end{array}$ & $\begin{array}{l}0.046 \\
0.703\end{array}$ & $\begin{array}{c}-0.078 \\
0.522\end{array}$ & $\begin{array}{l}0.103 \\
0.394\end{array}$ & $\begin{array}{l}0.215 \\
0.073\end{array}$ & $\begin{array}{l}0.199 \\
0.098\end{array}$ & $\begin{array}{c}0.641^{* *} \\
0.000\end{array}$ & 1.000 & & \\
\hline (12) BC & $\begin{array}{c}0.375^{* *} \\
0.001\end{array}$ & $\begin{array}{c}0.394^{* * *} \\
0.001\end{array}$ & $\begin{array}{c}0.504^{* * *} \\
0.000\end{array}$ & $\begin{array}{l}0.253 \\
0.035\end{array}$ & $\begin{array}{c}0.464^{* * *} \\
0.000\end{array}$ & $\begin{array}{c}0.502^{* * *} \\
0.000\end{array}$ & $\begin{array}{c}0.464 * * \\
0.000\end{array}$ & $\begin{array}{l}0.247 \\
0.040\end{array}$ & $\begin{array}{c}0.468^{* *} \\
0.000\end{array}$ & $\begin{array}{l}0.122 \\
0.316\end{array}$ & $\begin{array}{l}0.190 \\
0.116\end{array}$ & 1.000 & \\
\hline (13) CS & $\begin{array}{l}0.099 \\
0.416\end{array}$ & $\begin{array}{c}0.298^{* *} \\
0.012\end{array}$ & $\begin{array}{l}0.286 \\
0.017\end{array}$ & $\begin{array}{l}0.262 \\
0.028\end{array}$ & $\begin{array}{l}0.258 \\
0.031\end{array}$ & $\begin{array}{l}0.311 \\
0.009\end{array}$ & $\begin{array}{l}0.328 \\
0.006\end{array}$ & $\begin{array}{l}0.259 \\
0.030\end{array}$ & $\begin{array}{l}0.328 \\
0.006\end{array}$ & $\begin{array}{l}0.368 \\
0.002\end{array}$ & $\begin{array}{l}0.409 \\
0.000\end{array}$ & $\begin{array}{l}0.673 \\
0.000\end{array}$ & 1.000 \\
\hline \multicolumn{14}{|c|}{ Variance inflation factor } \\
\hline \multicolumn{9}{|c|}{ VIF } & \multicolumn{5}{|c|}{$1 / \mathrm{VIF}$} \\
\hline \multicolumn{4}{|c|}{ CLNGTH } & \multicolumn{5}{|c|}{2.139} & \multicolumn{5}{|c|}{.468} \\
\hline \multicolumn{4}{|c|}{ ACFPS } & \multicolumn{5}{|c|}{2.105} & \multicolumn{5}{|c|}{.475} \\
\hline \multicolumn{4}{|c|}{ SWPG } & \multicolumn{5}{|c|}{1.684} & \multicolumn{5}{|c|}{.594} \\
\hline \multicolumn{3}{|c|}{ ROD } & & \multicolumn{5}{|c|}{1.371} & \multicolumn{5}{|c|}{.73} \\
\hline \multicolumn{4}{|c|}{ MEAN VIF } & \multicolumn{5}{|c|}{1.825} & \\
\hline
\end{tabular}

Table 3

Effect of Contract Management Firm performance

\begin{tabular}{|c|c|c|c|c|c|}
\hline VARIABLES & $\begin{array}{c}\text { (1) } \\
\text { Model 1: Nature of } \\
\text { Solution } \\
\end{array}$ & $\begin{array}{c}(2) \\
\text { Model 2: Effectiveness of } \\
\text { Solution } \\
\end{array}$ & $\begin{array}{l}\text { (3) } \\
\text { Model 3: effectiveness in } \\
\text { future }\end{array}$ & $\begin{array}{c}\text { (4) } \\
\text { Model 4: support for } \\
\text { solution }\end{array}$ & $\begin{array}{c}\text { (5) } \\
\text { Model 5: Cost \& benefit } \\
\text { Analysis }\end{array}$ \\
\hline Contract Length (CLNGTH) & $\begin{array}{l}0.488^{* *} \\
(0.239)\end{array}$ & $\begin{array}{l}0.00857 \\
(0.188)\end{array}$ & $\begin{array}{l}0.0961 \\
(0.186)\end{array}$ & $\begin{array}{c}0.509 * * * \\
(0.147)\end{array}$ & $\begin{array}{l}0.393^{* *} \\
(0.154)\end{array}$ \\
\hline Satisfaction with project goals (SWPG) & $\begin{array}{c}0.125 \\
(0.198)\end{array}$ & $\begin{array}{c}0.603 * * * \\
(0.141)\end{array}$ & $\begin{array}{c}0.615 * * * \\
(0.131)\end{array}$ & $\begin{array}{l}-0.0906 \\
(0.152)\end{array}$ & $\begin{array}{l}0.305^{* *} \\
(0.145)\end{array}$ \\
\hline Resolution of dispute (ROD) & $\begin{array}{c}-0.304 * * \\
(0.145)\end{array}$ & $\begin{array}{l}-0.289 \\
(0.158)\end{array}$ & $\begin{array}{l}-0.113 \\
(0.120)\end{array}$ & $\begin{array}{c}0.188 \\
(0.155)\end{array}$ & $\begin{array}{c}0.0391 \\
(0.0827)\end{array}$ \\
\hline $\begin{array}{l}\text { Acceptance Criteria for Product/Service } \\
\text { (ACFPS) }\end{array}$ & $\begin{array}{r}-0.0273 \\
(0.242)\end{array}$ & $\begin{array}{l}0.374^{*} \\
(0.215)\end{array}$ & $\begin{array}{l}0.125 \\
(0.207)\end{array}$ & $\begin{array}{r}-0.0560 \\
(0.183)\end{array}$ & $\begin{array}{l}0.309^{*} \\
(0.175)\end{array}$ \\
\hline Constant & $\begin{array}{l}2.226^{* * *} \\
(0.776)\end{array}$ & $\begin{array}{c}0.736 \\
(0.918)\end{array}$ & $\begin{array}{c}0.664 \\
(0.677)\end{array}$ & $\begin{array}{l}1.780^{*} \\
(0.982)\end{array}$ & $\begin{array}{r}-0.0904 \\
(0.623)\end{array}$ \\
\hline Observations & 70 & 70 & 70 & 70 & 70 \\
\hline R-squared & 0.231 & 0.414 & 0.433 & 0.214 & 0.469 \\
\hline
\end{tabular}


Regression findings for the first five dimensions of firm performance through contract management is presented in Table 3. For the project management, five variables are selected and measured on the Likert scale, covering the title of contract length (CLNGTH), satisfaction with the project goals (SWPG), resolution of dispute (ROD), and acceptance criteria for product/service (ACPS). To measure the performance of the business, nine items are added, ranging from Model1 to Mode19. Model 1 to Model 4 reflecting the business performance through conflict management with the customers. Model 5 reflects cost benefit analysis, while Model 6 to Model 9 indicates the project quality, project delivery on time, budgetary compliance, and finally customer satisfaction. Effect of first explanatory variable for the project management (CLNGTH) indicates its significantly positive influence on nature of the solution. It means that time duration to complete a project in project management directly impacting on performance measurement through nature of solution. This effect is significant at 5 percent with the standard error of .239. For model2, the effectiveness of solution is considered as the main proxy for business performance through project management. For EOS, the impact of contract length is found to be positively insignificant, while the factor of SWPG indicating a coefficient of .603 with the standard error of .141, respectively. It means that more satisfaction with the project goals leading to more effectiveness of solution in Indonesia. For the effectiveness in future, the impact of SWPG is positively significant at 1 percent. While support for the solution expresses a negative but insignificant relationship with SWPG. For the $\operatorname{cost} \&$ benefit analysis, it is found that SWPG has a positive influence at 5 percent level of significance. For resolution of dispute ROD, coefficient is -.304 for nature of the solution indicating significantly negative relationship between the both. Company performance through acceptance criteria through product/service, impact on effectiveness of solution and cost \& benefit analysis have coefficients of .374 and .309 , respectively significant at 10 percent. Model 3 reflects the explanatory power of 43.3 percent, while model 5 indicates 46.9. The lowest value relates to model 1; 23 percent.

Table 4 presents the findings for the Model6 to Mode19, covering the project quality (PQ), on time delivery (OND), budgetary compliance (BC), and customer satisfaction (CS). It is found that contract length had a significant but negative influence of -.506 on project quality. This association expresses the fact that contract length leading to an adverse effect on project quality. For project delivery, coefficient is .606 with the standard error of .236. More length of the contract leads to lowering the project quality. However, for budgetary compliance and customer satisfaction, impact of contract length is insignificant. In addition, satisfaction with the project goals had a significantly positive influence on budgetary compliance. While the factor of resolution for dispute indicates a significant association with project quality. For Acceptance Criteria for Product/Service, coefficient is .462, reflecting the significant and positive relationship with the project delivery on time. As per the explained variation, maximum value links to model 8 followed by model 9 and model 7 respectively.

Table 4

Effect of Contract Management on Firm performance

\begin{tabular}{|c|c|c|c|c|}
\hline VARIABLES & $\begin{array}{c}\text { (1) } \\
\text { Model 6: Project Quality }\end{array}$ & $\begin{array}{c}(2) \\
\text { Model 7: Project Delivery }\end{array}$ & $\begin{array}{c}(3) \\
\text { Model 8: Budgetary } \\
\text { Compliance }\end{array}$ & $\begin{array}{c}(4) \\
\text { Model 9: Custome } \\
\text { Satisfaction }\end{array}$ \\
\hline Contract Length (CLNGTH) & $\begin{array}{c}-0.506^{* *} \\
(0.234)\end{array}$ & $\begin{array}{c}-0.606 * * \\
(0.236)\end{array}$ & $\begin{array}{c}0.249 \\
(0.155)\end{array}$ & $\begin{array}{l}0.0625 \\
(0.183)\end{array}$ \\
\hline Satisfaction with project goals (SWPG) & $\begin{array}{c}0.250 \\
(0.230)\end{array}$ & $\begin{array}{c}0.284 \\
(0.204)\end{array}$ & $\begin{array}{r}0.256^{* *} \\
(0.100)\end{array}$ & $\begin{array}{c}0.261 \\
(0.179)\end{array}$ \\
\hline Resolution of dispute (ROD) & $\begin{array}{l}0.321^{*} \\
(0.178)\end{array}$ & $\begin{array}{c}0.246 \\
(0.168)\end{array}$ & $\begin{array}{c}0.103 \\
(0.134)\end{array}$ & $\begin{array}{c}0.223 \\
(0.184)\end{array}$ \\
\hline $\begin{array}{l}\text { Acceptance Criteria for Product/Service } \\
\text { (ACFPS) }\end{array}$ & $\begin{array}{c}0.309 \\
(0.253)\end{array}$ & $\begin{array}{l}0.462 * \\
(0.252)\end{array}$ & $\begin{array}{l}0.241 \\
(0.199)\end{array}$ & $\begin{array}{l}0.135 \\
(0.230)\end{array}$ \\
\hline Constant & $\begin{array}{c}2.023^{* * * *} \\
(0.672)\end{array}$ & $\begin{array}{l}1.961^{* *} \\
(0.764)\end{array}$ & $\begin{array}{c}0.765 \\
(0.876)\end{array}$ & $\begin{array}{l}1.471 \\
(0.979)\end{array}$ \\
\hline Observations & 70 & 70 & 70 & 70 \\
\hline R-squared & 0.145 & 0.159 & 0.328 & 0.175 \\
\hline
\end{tabular}




\section{Conclusion and Recommendations}

This study has been conducted to evaluate the effect of project management on performance of the firms in the region of Indonesia. To develop a structural questionnaire, various items reflecting the contract management and firm performance were extracted from existing literature with the demographic factors. A sample of 70 respondents has been collected through physical delivery of the questionnaire. Various factors like contract length, satisfaction with project goals, dispute resolution and acceptance criteria for the product/services were added in the model to cover the concept of contract management. For the firm performance 9 items have been finalized covering the dispute resolution with the customer, cost benefit analysis, project delivery, project quality, on time delivery, budgetary compliance and customer satisfaction. Findings of the study have indicated that contract length was positively associated with nature of the solution, cost benefit analysis, and support for the solution. While satisfaction with the project goals was significantly and positively related to cost benefit analysis of the project. Acceptance criteria for the product/service was significantly and positively linked to effectiveness of the solution and cost benefit analysis. Both the factor of project quality and on time delivery were negatively associated with the contract length. Resolution of dispute was positively associated with project quality. These findings are providing enough evidence for the various firms, working on various private and public sector contracts. Meanwhile, contact management covering the title of conflict resolution with the customer is of significant interest for those firms dealing with the project management. This study has successfully interlinked the various topics for the business performance, which are not under significant attention in earlier research. Limitations of the study covers the concept like limited sample size, limited consideration of the variables. Future studies can be conducted while covering these limitations with better sample.

\section{References}

Adams, F. K. (2008). Construction contract risk management: a study of practices in the United Kingdom. Cost Engineering, 50(1), 22-33.

Ahmed, U., Majid, A. H. A., \& Zin, M. L. M. (2016). HR Moderating HR: Critical link between Developmental HR Practices and work engagement in a Moderated Model. Management Review: An International Journal, 11(2), 4.

Ajayi, S. O., Oyedele, L. O., Bilal, M., Akinade, O. O., Alaka, H. A., Owolabi, H. A., \& Kadiri, K. O. (2015). Waste effectiveness of the construction industry: Understanding the impediments and requisites for improvements. Resources, Conservation and Recycling, 102, 101-112.

Albasu, J., \& Nyameh, J. (2017). Relevance of stakeholders theory, organizational identity theory and social exchange theory to corporate social responsibility and employees performance in the commercial banks in Nigeria. International Journal of Business, Economics and Management, 4(5), 95-105.

Alexander, J. A., \& Morrisey, M. A. (1989). A resource-dependence model of hospital contract management. Health Services Research, 24(2), 259.

Anigbogu, U. E., \& Nduka, E. K. (2014). Stock market performance and economic growth: Evidence from Nigeria employing vector error correction model framework. The Economics and Finance Letters, 1(9), 90-103.

Anyanwu, J. O., Okoroji, L. I., Ezewoko, O. F., \& Nwaobilor, C. A. (2016). The impact of training and development on workers performance in Imo State. Global Journal of Social Sciences Studies, 2(2), 51-71.

Bayliss, R., Cheung, S.-O., Suen, H. C., \& Wong, S.-P. (2004). Effective partnering tools in construction: a case study on MTRC TKE contract 604 in Hong Kong. International Journal of Project Management, 22(3), 253-263.

Blumenberg, S., Wagner, H.-T., \& Beimborn, D. (2009). Knowledge transfer processes in IT outsourcing relationships and their impact on shared knowledge and outsourcing performance. International Journal of Information Management, 29(5), 342-352. 
Broekhuis, M., \& Scholten, K. (2018). Purchasing in service triads: the influence of contracting on contract management. International Journal of Operations \& Production Management, 38(5), 11881204.

Brun, A., \& Moretto, A. (2012). Contract design and supply chain management in the luxury jewellery industry. International Journal of Retail \& Distribution Management, 40(8), 607-628.

Chang, W. S., \& Liang, C. (2015). Exploring potential entrants' perceptions of the performance of an agrirural social enterprise in Taiwan. International Journal of Management and Sustainability, 4(10), 205-217.

Chielotam, A. N. (2015). Oguamalam masquerade performance beyond aesthetics. Humanities and Social Sciences Letters, 3(2), 63-71.

Chow, P.-S., Wang, Y., Choi, T.-M., \& Shen, B. (2015). An experimental study on the effects of minimum profit share on supply chains with markdown contract: Risk and profit analysis. Omega, 57, 8597.

Crookshanks, R. J. (2006). Building construction bid and contract management system, internet-based method and computer program therefor: Google Patents.

Domberger, S., Fernandez, P., \& Fiebig, D. G. (2000). Modelling the price, performance and contract characteristics of IT outsourcing. Journal of Information Technology, 15(2), 107-118.

Duarte, M., \& Davies, G. (2003). Testing the conflict-performance assumption in business-to-business relationships. Industrial Marketing Management, 32(2), 91-99.

Flammer, C. (2015). Does corporate social responsibility lead to superior financial performance? A regression discontinuity approach. Management Science, 61(11), 2549-2568.

Gao, L. (2015). Collaborative forecasting, inventory hedging and contract coordination in dynamic supply risk management. European Journal of Operational Research, 245(1), 133-145.

Goddard, B. L. (2000). Termination of a contract to implement an enterprise electronic medical record system. Journal of the American Medical Informatics association, 7(6), 564-568.

Haapio, H., \& Siedel, G. J. (2017). A short guide to contract risk. Routledge.

Hobday, M. (2000). The project-based organisation: an ideal form for managing complex products and systems? Research policy, 29(7-8), 871-893.

Husted, B. W., \& de Jesus Salazar, J. (2006). Taking Friedman seriously: Maximizing profits and social performance. Journal of Management studies, 43(1), 75-91.

Hyvönen, T., \& Järvinen, J. (2006). Contract-based budgeting in health care: a study of the institutional processes of accounting change. European Accounting Review, 15(1), 3-36.

Jenkins, G. P. (1999). Evaluation of stakeholder impacts in cost-benefit analysis. Impact Assessment and Project Appraisal, 17(2), 87-96.

Jones Osasuyi, O., \& Mwakipsile, G. (2017). Working capital management and managerial performance in some selected manufacturing firms in Edo State Nigeria. Journal of Accounting, Business and Finance Research, 1(1), 46-55.

Kamminga, P. (2015). Rethinking contract design: Why incorporating non-legal drivers of contractual behavior in contracts may lead to better results in complex defense systems procurement. Journal of Public Procurement, 15(2), 208-235.

Kartam, N. A., \& Kartam, S. A. (2001). Risk and its management in the Kuwaiti construction industry: a contractors' perspective. International Journal of Project Management, 19(6), 325-335.

Kerzner, H., \& Kerzner, H. R. (2017). Project management: a systems approach to planning, scheduling, and controlling. John Wiley \& Sons.

Klijn, E. H., \& Koppenjan, J. (2016). The impact of contract characteristics on the performance of publicprivate partnerships (PPPs). Public Money \& Management, 36(6), 455-462.

Kochan, T., Bezrukova, K., Ely, R., Jackson, S., Joshi, A., Jehn, K., ... \& Thomas, D. (2003). The effects of diversity on business performance: Report of the diversity research network. Human Resource Management: Published in Cooperation with the School of Business Administration, The University of Michigan and in alliance with the Society of Human Resources Management, 42(1), 3-21.

Kucukkocaoglu, G., \& Bozkurt, M. A. (2018). Identifying the effects of mergers and acquisitions on Turkish banks performances. Asian Economic and Financial Review, 6(3), 235-244. 
Le, H. L., Vu, K. T., Du, N. K., \& Tran, M. D. (2018). Impact of working capital management on financial performance: The case of Vietnam. International Journal of Applied Economics, Finance and Accounting, 3(1), 15-20.

Liu, J., Meng, F., \& Fellows, R. (2015). An exploratory study of understanding project risk management from the perspective of national culture. International Journal of Project Management, 33(3), 564575.

Loevinsohn, B., \& Harding, A. (2005). Buying results? Contracting for health service delivery in developing countries. The Lancet, 366(9486), 676-681.

Logan, M. S. (2000). Using agency theory to design successful outsourcing relationships. The International Journal of Logistics Management, 11(2), 21-32.

Malarvizhi, C. A., Nahar, R., \& Manzoor, S. R. (2018). The strategic performance of Bangladeshi private commercial banks on post implementation relationship marketing. International Journal of Emerging Trends in Social Sciences, 2(1), 28-33.

Maldonado-Guzman, G., Marin-Aguilar, J., \& Garcia-Vidales, M. (2018). Innovation and performance in Latin-American small family firms. Asian Economic and Financial Review, 8(7), 1008-1020.

Maroofi, F., Ardalan, A. G., \& Tabarzadi, J. (2017). The Effect of Sales Strategies in the Financial Performance of Insurance Companies. International Journal of Asian Social Science, 7(2), 150-160.

McGuire, J. B., Sundgren, A., \& Schneeweis, T. (1988). Corporate social responsibility and firm financial performance. Academy of management Journal, 31(4), 854-872.

Mchopa, A. (2015). Integrating contract management practices into the achievement of value for money in tanzania public procurement: Evidence from selected procuring entities in moshi municipality. Journal of Public Procurement, 15(2), 129-149.

Mo, B., Gjelsvik, A., \& Grundt, A. (2001). Integrated risk management of hydro power scheduling and contract management. IEEE Transactions on Power Systems, 16(2), 216-221.

Morris, P., \& Jamieson, H. (2004). Linking corporate strategy to project strategy via portfolio and program management.

Mosbah, A., Serief, S. R., \& Wahab, K. A. (2017). Performance of family business in Malaysia. International Journal of Social Sciences Perspectives, 1(1), 20-26.

Mowlaei, M. (2017). The impact of AFT on export performance of selected Asian developing countries. Asian Development Policy Review, 5(4), 253-261.

Mutua, J. M., Waiganjo, E., \& Oteyo, I. N. (2014). The influence of contract management on performance of outsourced projects in medium manufacturing enterprises in Nairobi County, Kenya. International Journal of Business and Social Science, 5(9).

Oberlender, G. D., \& Oberlender, G. D. (1993). Project management for engineering and construction (Vol. 2). McGraw-Hill New York.

Omizzolo Lazzarotto, B., Borchardt, M., Pereira, G., \& Almeida, C. (2014). Analysis of management practices in performance-based outsourcing contracts. Business Process Management Journal, 20(2), 178-194.

Orlitzky, M., Schmidt, F. L., \& Rynes, S. L. (2003). Corporate social and financial performance: A metaanalysis. Organization studies, 24(3), 403-441.

Pappas, K., Walsh, E., \& Xu, A. L. (2019). Real earnings management and Loan Contract terms. The British Accounting Review.

Pearce, D., Atkinson, G., \& Mourato, S. (2006). Cost-benefit analysis and the environment: recent developments: Organisation for Economic Co-operation and development.

Post, C., \& Byron, K. (2015). Women on boards and firm financial performance: A meta-analysis. Academy of management Journal, 58(5), 1546-1571.

Purnama, C. (2014). Improved performance through empowerment of small industry. Journal of Social Economics Research, 1(4), 72-86.

Qiu, Y., Shaukat, A., \& Tharyan, R. (2016). Environmental and social disclosures: Link with corporate financial performance. The British Accounting Review, 48(1), 102-116.

Quah, E., \& Haldane, J. (2007). Cost-benefit analysis. Routledge. 
Rasheli, G. A. (2016). Procurement contract management in the local government authorities (LGAs) in Tanzania: A transaction cost approach. International Journal of Public Sector Management, 29(6), 545-564.

Ryall, M. D., \& Sampson, R. C. (2016). Contract structure for joint production: risk and ambiguity under compensatory damages. Management Science, 63(4), 1232-1253.

Sackler, A. F., \& Levin, M. (1993). Health insurance management system: Google Patents.

Santhi, N. S., \& Gurunathan, K. B. (2014). Fama-French three factors model in Indian mutual fund market. Asian Journal of Economics and Empirical Research, 1(1), 1-5.

Selviaridis, K., \& Norrman, A. (2015). Performance-based contracting for advanced logistics services: Challenges in its adoption, design and management. International Journal of Physical Distribution \& Logistics Management, 45(6), 592-617.

Simon, R. I. (1999). The suicide prevention contract: clinical, legal, and risk management issues. Journal of the American Academy of Psychiatry and the Law Online, 27(3), 445-450.

Soeters, R., \& Griffiths, F. (2003). Improving government health services through contract management: a case from Cambodia. Health policy and planning, 18(1), 74-83.

Thomas, K. W. (1992). Conflict and conflict management: Reflections and update. Journal of Organizational Behavior, 13(3), 265-274.

Turner, J. R., \& Simister, S. J. (2001). Project contract management and a theory of organization. International Journal of Project Management, 19(8), 457-464.

Waddock, S. A., \& Graves, S. B. (1997). The corporate social performance-financial performance link. Strategic Management Journal, 18(4), 303-319.

Wiengarten, F., Humphreys, P., Gimenez, C., \& McIvor, R. (2016). Risk, risk management practices, and the success of supply chain integration. International Journal of Production Economics, 171, 361370.

Zhi, H. (1995). Risk management for overseas construction projects. International Journal of Project Management, 13(4), 231-237.

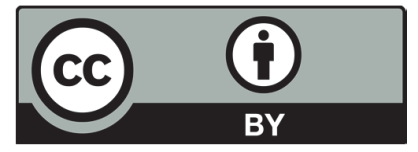

(C) 2019 by the authors; licensee Growing Science, Canada. This is an open access article distributed under the terms and conditions of the Creative Commons Attribution (CCBY) license (http://creativecommons.org/licenses/by/4.0/). 